\title{
마그레브 지역 고용정책에 대한 고찰 및 공적개발원조의 시사점
}

김창건 (KOICA 중장기자문단)

\section{목 차}
I. 서론
II. 마그레브 3 개국 경제발전 과정
III. 마그레브 3 개국 노동시장 현황
IV. 마그레브 3 개국 노동시장 정책 및 사례
V. 맺는말

\section{I. 서론}

지중해 연안에 위치한 마그레브 3국1)인 알제리·모로코·튀니지는 아프리카와 유럽 및 중동지역을 잇는 전략적 요충지이다. 특히 튀니지는 천만 명의 인구와 한반도의 3/4 정도의 면적을 가진 북아프리카의 작은 나라이다. 그러나 지난 2010년 12월 튀니지 시디브지드(Sidi Bouzid) 한 청년의 분신자살로 촉발되었던 재스민 혁명은 인근 국가는 물론 아랍 지역의 민주화 열풍을 가져왔다. 일명 '아랍의 봄' 이라 일컬어지는 시민혁명 결과 튀니지에서는 1987년부터 장기 집권하던 벤 알리 대통령이 2011년 1 월 사우디로 추방당하였으며 리비아.이집트.예멘에서는 장기 집권하던 독재정권이 물러났다.

당시 시민혁명 운동은 높은 실업률, 특히 고학력자들의 높은 청년 실업률이 가장 큰 원인이었다 (Champante and Chor 2012). 이 지역의 높은 청년 실업률은 경제학자들의 주목을 받고 있으며, 세계은행을 비롯한 국제기구의 관심이 집중되고 있다. 이에 마그레브 3국은 청년 실업률 해소를 위하여 다양한 고용정책을 실시하고 있으며, 높은 비율의 정부 지출이 청년 일자리 창출정책에 집중되고 있다.

1) 마그레브란 아랍어로 해가 지는 서쪽을 의미(김시경 2003:116). 통상적으로 마그레브 국가는 알제리, 모로코, 튀니지, 리비아 및 모리타니 국가를 포함한 5 개국이나 프랑스권 사용국가가 아닌 리비아 및 경제규모가 미약한 모리타니는 본 연구대상에서 제외한다. 
이러한 현상은 향후에도 당분간 지속될 전망이고, 청년 실업문제를 해결하는 과제는 결코 쉬워 보이지 않는다.

기존 마그레브 지역의 경제현안과 관련된 연구는 마그레브 국가들의 경제구조나 통상현황에 대한 연구(김시경 2003) 및 튀니지의 경제현황에 대한 연구가 있다(김중관 2007). 그러나 마그레브 지역의 노동시장에 대해 심층적으로 분석한 연구는 없는 실정이다. 다만 북아프리카 및 중동지역의 산유국인 사우디아라비아와 아랍 에미리트의 노동시장을 조사한 연구가 유일하다(한바란 외 2011). 이에 본고에서는 마그레브 3 개국의 노동시장 현황과 다양한 고용 정책에 대해서 살펴보고자 한다.

본 연구는 기존 문헌의 연구결과 고찰 및 세계은행을 비롯한 국제기구의 통계자료와 현지 조사 및 현지 관계자의 인터뷰를 통해 관련 부분의 사실을 뒷받침할 것이다.2) 이를 위해 본 논문은 크게 3장으로 구성하였다. 제 2 장에서는 마그레브 3 개국의 경제 발전 과정에 대해서 살펴보고, 제 3 장에서는 마그레브 3 개국 노동시장의 현황에 대해서 관찰해 보기로 한다. 제4장에서는 마그레브 3 개국의 일자리 창출을 위한 노동시장 정책 및 사례에 대해서 살펴보고자 한다.

본 논문은 청년 일자리 창출과 관련된 고용정책을 고찰해 봄으로서 이 지역 노동시장의 이해를 높이고 아프리카 및 중동 지역의 개발도상국 일자리 창출과 관련된 공적개발원조의 시사점을 제시할 수 있을 것이라 기대한다.

\section{II. 마그레브 3 개국 경제 발전과정}

2012년 말 기준 알제리, 모로코 및 튀니지 3개국의 경제규모는 아프리카 GDP의 $17 \%$ 를 차지하고 있으며, 일인당 GDP는 알제리 5,287불, 튀니지 4,155불, 모로코 2,946불로 아프리카 평균 일인당 GDP 1,883 불을 크게 상회하고 있다. 세계은행 국가 분류기준에 따르면 모로코를 제외한 알제리와 튀니지는 상위 중립국가로 구분된다. 3개국은 1950년대와 1960년대에 걸쳐 프랑스로부터 독립한 국가들로 프랑스어와 아랍어를 공용어로 쓰고 사회 문화적으로 비슷한 공통점이 있는 반면, 경제발전 과정은 서로 상이한 구조를 가지고 있다. 알제리는 아프리카에서 나이지리아, 리비아 다음으로 석유와 천연가스 매장량이 풍부한 국가이다. 이와 달리 천연자원이 부족한 모로코와 튀니지는 일찍이 산업화 및 시장개방정책을 취해 왔으며, 자국인들이 인근 산유국에서 벌어들인 해외 송금액 및 국제사회의 원조 의존도가 높은 편이다.

2) 그러나 이 지역 노동시장의 연구에 가장 큰 제약요소로 분석에 필요한 데이터 수집이 용이하지 않는다는 점, 존재하는 통계에 대해서도 외부 접근성이 용이하지 않은 점, 시일 지난 통계를 바탕으로 분석을 할 수 밖에 없다는 한계가 존재한다는 것은 이미 알려진 바와 같다(한바란 외 2011:25). 


\section{1. 경제 발전 과정 : 1960년대 2000년대}

1960년대부터 1980년대 중반까지 이 지역의 경제성장 모형은 강력한 국가의 주도하에 경제 인프라 구축 및 자국 시장을 보호하는 정책이었다(세계은행 2013b:91). 산유국인 알제리는 오일 수출로 축적된 부로, 상대적으로 자원이 부족한 모로코와 튀니지는 해외 송금액이 크게 증가하면서 경제 인프라 구축, 교육 및 병원 등 많은 공공자본 투자가 경제성장을 주도했다.

<표 1>에서 볼 수 있듯이 1960년대와 1970년대 GDP 성장률은 모로코를 제외하고 3\%대3)를 보여주고 있으며, 물적자본 및 인적자본 투자도 상당 부문 이루어졌다. 하지만 알제리와 모로코의 총 요소생산성은 이러한 투자에 비해 마이너스를 기록해 투입되는 자본이 생산성의 증가로 이어지지 못했음을 보여준다. 1980년대 오일 쇼크의 영향으로 자원이 풍부한 알제리 GDP 성장률은 마이너스를 기록하게 되고 그 여파는 1990년대까지 이어져 물적자본의 투자도 1960년대와 1970년대에 비해 감소했다. 자원이 부족한 모로코와 튀니지도 오일 쇼크의 영향이 알제리에 비해 상대적으로 덜 하였어도 물적자본 및 인적자본의 투자는 1960년대와 1970년대에 비해 큰 폭으로 줄어들었다. 이런 거시경제의 충격으로 모로코와 튀니지는 과감한 경제개혁을 실시하여 북 아프리카 및 중동지역에서는 다른 국가들에 비해 일찍이 해외수출로 눈을 돌리는 시장개방 정책 및 산업화 정책을 취하기 시작했다 (세계은행 2013b:92). 2000년대에 들어서면서 제2의 오일 붐 영향으로 GDP 성장률은 다시 증가세로 돌아섰지만 물적자본 및 인적자본의 투자는 예전 수준으로 돌아가지 못하였다.

<표 1> GDP, 물적자본, 인적자본 및 총 요소생산성 증가율

(단위: \%)

\begin{tabular}{c|c|c|c|c|c}
\hline 국가 & 시기 & GDP & 물적자본 & 인적자본 & 총 요소 생산성 \\
\hline \multirow{4}{*}{ 알제리 } & 1960년대 & 3.0 & 1.4 & 0.6 & 2.1 \\
\cline { 2 - 6 } & 1970년대 & 2.7 & 5.3 & 1.1 & -0.1 \\
\cline { 2 - 6 } & 1980년대 & -1.3 & 0.3 & 0.7 & -2.3 \\
\cline { 2 - 6 } & 1990년대 & -3.1 & -1.0 & 0.6 & -2.5 \\
\cline { 2 - 6 } & 2000년대 & 0.2 & -0.3 & 0.4 & 0.2 \\
\hline \multirow{5}{*}{ 모로코 } & 1960년대 & 2.2 & 1.8 & -3.2 & 3.5 \\
\cline { 2 - 6 } & 1970년대 & 1.0 & 4.3 & 0.8 & -1.2 \\
\cline { 2 - 6 } & 1980년대 & 0.8 & 0.4 & 0.4 & 0.0 \\
\cline { 2 - 6 } & 1990년대 & -0.3 & 0.2 & 0.3 & -0.9 \\
\cline { 2 - 6 } & 2000년대 & 3.0 & 0.8 & 0.3 & 1.8 \\
\hline
\end{tabular}

3) 북아프리카 및 중동지역의 1960 년대 GDP 증가율은 $7 \%$ 로 세계에서 가장 높은 경제성장을 기록하였다(세계은행 2013b:92). 


\begin{tabular}{c|c|c|c|c|c}
\hline \multirow{2}{*}{ 국가 } & 시기 & GDP & 물적자본 & 인적자본 & 총 요소 생산성 \\
\hline \multirow{7}{*}{ 튀니지 } & 1960년대 & 3.4 & 4.6 & 0.9 & 1.0 \\
\cline { 2 - 6 } & 1970년대 & 2.8 & 2.4 & 1.5 & 0.9 \\
\cline { 2 - 6 } & 1980년대 & 0.4 & 0.7 & 0.4 & -0.7 \\
\cline { 2 - 6 } & 1990년대 & 2.0 & 0.3 & 0.5 & 1.2 \\
\cline { 2 - 6 } & 2000년대 & 2.5 & 0.6 & 0.5 & 1.5 \\
\hline
\end{tabular}

주: GDP, 물적자본 및 인적자본 증가율은 근로자 일인당 기준.

출처: World Bank(2013b:109).

<그림 1>은 1976년부터 2012년까지 천연자원 수출, 해외송금 및 해외원조 부문이 GDP에서 차지하는 비중을 보여주고 있다. 천연자원이 풍부한 알제리는 천연자원의 수출 가격 변동으로 GDP 에서 차지하는 비중이 크게 변동하여 1차 오일 붐(1970년대 중후반) 및 2차 오일 붐(2003년 2005년) 시기에는 비중이 $40 \%$ 를 상회 하였다. 상대적으로 천연자원이 풍부하지 못한 모로코와 튀니지도 오일 붐에 힘입어 해외로 이주한 근로자들이 벌어들인 해외송금과 국제사회의 원조 비중이 꾸준하게 GDP 의 $10 \%$ 를 상회 했다. 결국 이런 불로소득(unearned income)으로 인한 국가주도의 발전이 3장에서 설명될 노동시장 문제의 “원죄(the original sin)”를 제공하였다(Malik and Awadallah 2013:297).

$<$ 그림 1> 천연자원, 해외송금, 원조가 GDP에서 차지하는 비중

(단위: \%)

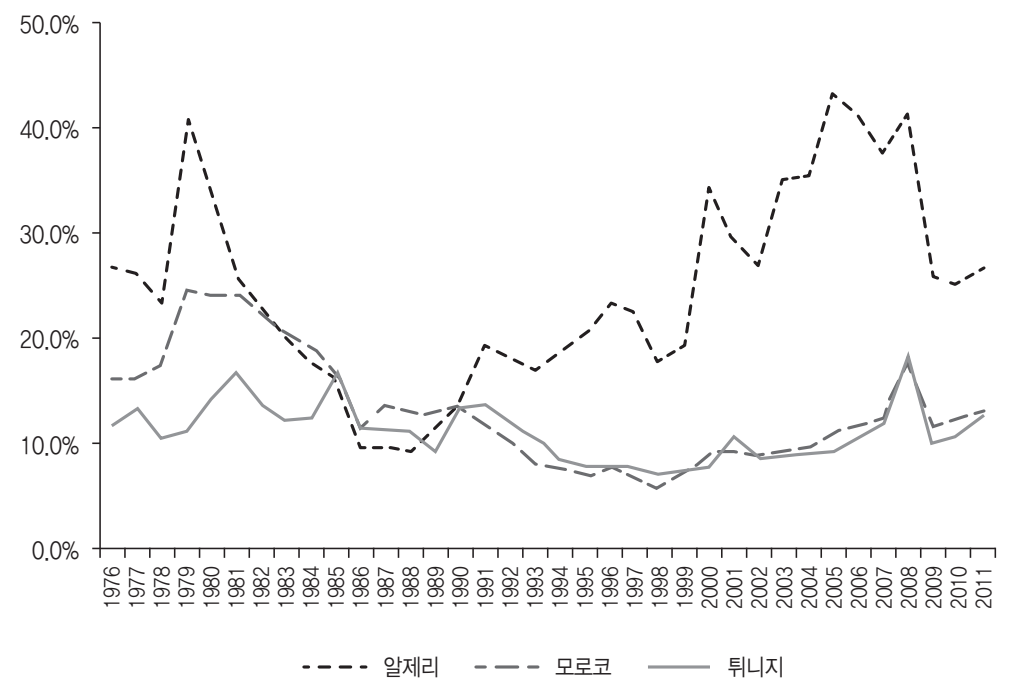

출처: 세계은행, World Development Indicators 2013. 


\section{2. 재스민 혁명 이후 거시경제 변화}

아랍지역은 전 세계적으로 가장 고립되어 있는 지역이다(Malik and Awadallah 2013: 299). 마그레브 국가 간의 교역은 $10 \%$ 가 채 안 되는 수준으로 재스민 혁명의 여파는 튀니지에 국한되었다. 튀니지의 실질 GDP는 2011년 1.9\%의 감소하였지만 2012년에는 3.7\%로 회복하였다. 경상수지와 무역수지 부분(4)에서는 지속적인 적자를 기록하고 있으며, 재스민 혁명이후 임시정부의 선심성 지출5)이 크게 늘면서 2012년에는 총 부채가 전체 GDP에서 차지하는 비중이 52\%에 달하고 있다. 튀니지에서 관광산업은 $\mathrm{GDP}$ 의 $6 \%$ 를 차지하고 있으며 관광산업에 종사하는 근로자의 비율은 전체 근로자의 $14 \%$ 를 차지할 정도로 중요한 산업이다. 재스민 혁명은 관광산업에 직접적인 영향을 미쳐 2011년 튀니지의 관광객 수는 2010년에 비해 33\% 감소하였지만 모로코는 튀니지 관광객의 이탈을 흡수하여 2010년에 비해 $8 \%$ 의 증가를 기록하였다.

<표 2> 3개국 주요 거시 경제 지표: 2009년 2012년

(단위: \%)

\begin{tabular}{|c|c|c|c|c|c|}
\hline 국가 & 구분 & 2009 & 2010 & 2011 & 2012 \\
\hline \multirow{5}{*}{ 튀니지 } & 실질 GDP 성장률 & 3.1 & 2.9 & -1.9 & 3.7 \\
\hline & 소비자물가 상승률 & 3.5 & 4.4 & 3.5 & 5.6 \\
\hline & 경상수지(GDP 비중) & -2.8 & -4.8 & -7.4 & -8.2 \\
\hline & 무역수지(GDP 비중) & -8.5 & -7.6 & 10.5 & -10.0 \\
\hline & 총 부채(GDP 비중) & 49.3 & 48.6 & 48.1 & 51.7 \\
\hline
\end{tabular}

출처: AfDB, Socio-Economic Database 2014.

\section{III. 마그레브 3 개국 노동시장 현황}

아랍 경제의 미래는 노동시장의 향방에 달려 있을 만큼 노동시장은 매우 중요하다(Yousef 2004:102). 청년 실업률의 심각성은 <그림 2>에 잘 나타나고 있다. 튀니지의 청년 실업률은 2012년 29.3\%로 세계 평균인 $12.6 \%$ 에 비해 두 배 이상 높은 수치를 기록하고 있다. 알제리의 15 24세 여성 실업률은 $36 \%$ 로 전 세계 평균인 $12.8 \%$ 의 세 배 정도 높은 수치를 보여주고 있다. 이번 장에서는 재스민 혁명의 직접적인 원인이 되었던 높은 청년 실업률의 원인에 대해서 살펴보기로 한다.

4) 2012 년 유럽지역이 수출량의 $76 \%$, 전체 수입량의 $71 \%$ 를 차지. 프랑스가 유럽 수출 $37 \%$, 수입 $26 \%$ 를 차지한다 (National Institute of Statistics, Tunisia Foreign Trade 2012).

5) 2011년 6월 임시정부는 경제하부구조가 열악한 내륙지방을 지원하기 위해 정부지출을 $11 \%$ 늘린다고 발표. 또한 공공기관에 2만 명의 일자리 창출 및 $\mathrm{AMAL}$ (추후 4장에서 설명)과 같은 노동시장정책을 발표하였다(AfDB 2012:39). 
<그림 2> 2012년 3개국 실업률 비교

(단위 : \%)

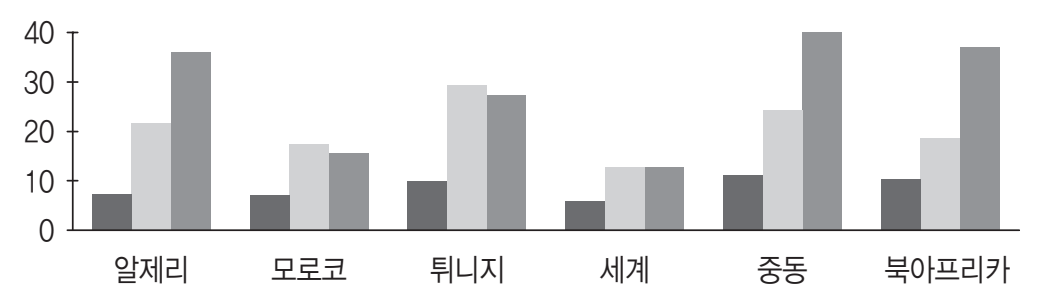

주: 전체는 25세 이상.

전체 15 15세 24세 에성 15세 24세

출처: ILO, Key Indicators of Labor Market, 8th Edition.

\section{1. 높은 청년 실업의 원인}

\section{1) 인구학적인 요인}

앞의 제 2 장에서 설명된 1960년대부터 1980년대까지 물적 자본 투자의 증가는 학교, 병원 등 사회 인프라 측면에서 많은 변화를 가져왔다. 개선된 의료부분의 사회 인프라는 국민보건의 향상으로 이어져 유아 사망률 감소와 1960년대 여성 한명 당 7명이라는 높은 출산율로 $2 \%$ 를 넘는 인구증가율을 가져왔다. 이와 같은 인구증가는 1990년대 경제활동 참가율(labor force participation rate) 증가를 가져와 15세 24세 사이 '청년팽창(youth bulge)'으로 이어지게 되었다. 우리나라를 비롯한 아시아 국가의 경우 인구학적 배당(demographic dividend)효과를 잘 활용하여 일인당 소득 증가, 저축 및 투자로 연계되어 1970 년대의 '아시아의 기적'을 가져온 반면 이 지역 국가들은 경제성장이 뒷받침되지 못해 높은 실업률6)을 초래한 것이다(Keller and Nabli 2002:6, Bloom and Canning 2004:21).

1990 년대 이후 여성 한 명당 출산율이 3 명 이하로 줄면서 인구증가율이 감소했음에도 불구하고 경제활동 참가율이 증가한 이유는 여성의 경제활동 증가에 기인한다. 하지만 <표 $3>$ 에서 볼 수 있듯이 2012년 15세 24세 여성의 경우 평균 20\% 정도만이 경제활동에 참여하고 있다. 이와 같은 수치는 세계 평균에 크게 못 미치는 수치로 특히 2012년 알제리의 15세 24세 여성 경제활동 참가율은 $10 \%$ 에도 못 미치는 수준이다. 3 개국 전체 인구에서 여성인구가 차지하는 비중이 $50 \%$ 임에도 불구하고 여성의 낮은 경제활동 참가율은 잠재적인 경제활동 인력이 제대로 활용되지 못함을 의미하며, 결국 경제의 생산성 증가에 부정적인 영향을 미칠 수밖에 없다.

6) 북 아프리카 및 중동지역의 1990년대 연 평균 경제활동 인구 증가율 $3.0 \%$ 은 우리나라의 1970 년대 경제활동 인구 증가율 $3.2 \%$ 와 유사하지만 이 지역 연 평균 GDP 성장률은 $3.6 \%$ 에 그친 반면 우리나라의 연 평균 GDP 성장률은 7.6\%에 달한다(Keller and Nabli 2002:6). 


\section{$<$ 표 3> 인구증가율, 경제활동 참가율 비교}

(단위: \%)

\begin{tabular}{|c|c|c|c|c|c|c|c|c|}
\hline & \multirow{2}{*}{\multicolumn{2}{|c|}{ 인구증가율 }} & \multirow{2}{*}{\multicolumn{2}{|c|}{$\begin{array}{c}\text { 경제활동 } \\
\text { 참가 증가율 }\end{array}$}} & \multicolumn{4}{|c|}{ 경제활동 참가율* } \\
\hline & & & & & \multicolumn{2}{|c|}{ 남자 } & \multicolumn{2}{|c|}{ 여자 } \\
\hline & ‘60 90 & ‘91 12 & '90 00 & ‘01 12 & 1990 & 2012 & 1990 & 2012 \\
\hline 알제리 & 2.9 & 1.8 & 3.9 & 2.5 & 54.8 & 47.3 & 10.8 & 9.6 \\
\hline 모로코 & 2.3 & 1.3 & 2.2 & 1.6 & 41.5 & 33.3 & 27.7 & 27.8 \\
\hline 튀니지 & 2.2 & 1.3 & 2.7 & 1.7 & 56.3 & 42.0 & 26.4 & 20.3 \\
\hline 세계 & 1.9 & 1.3 & 1.7 & 1.4 & 67.3 & 55.6 & 51.0 & 39.1 \\
\hline
\end{tabular}

주: 경제활동 참가율은 15 세에서 24 세 기준

출처: 세계은행, World Development Indicators 2013

\section{2) 교육시스템}

알제리는 1979년 GDP의 7.2\%를 인적자본에 투자했고, 과거 40년 동안 마그레브 3개국은 세계 어떤 지역보다도 인적자본에 많은 투자를 했다(세계은행 2008:11). 이런 양적 투자는 학교 등록률 및 학력 수준별 성별 동등지수(gender parity index)에서 괄목한 만한 성과를 가져왔다(<그림 3> 참조). 1970년대 오일 수출은 교육비에 집중적인 투자를 가져오게 되었다. 오일이 나지 않는 나라도 해외송금 및 해외원조의 증가로 국가의 수입이 증가 되고 정부기관과 공기업의 일자리를 만들어 증가하는 대학 졸업생을 채용하기 시작하였다. 이것이 바로 '아랍지역의 과잉교육(over-educated Arab)' 현상으로 (Pissarides 1993:18) 학교 졸업장은 공공부문에 취직을 할 수 있는 일종의 관문으로만 취급되었다 (Yousef 2004:103).

하지만 국가의 인위적인 고용 정책은 오래 지속되지 못하였다. 1980년대 오일 쇼크 이후 각 국은 경제개혁을 실시하기 시작하였다. 그 일환으로 공기업 민영화, 정부기관 축소 등의 구조조정을 시작하면서 정부가 마지막 고용을 창출하는 역할(employer of last resort)은 끝이 나기 시작했다. 하지만 교육 시스템은 여전히 시장수요에 맞는 기술을 가르치기 보다는 공공부문 취직에 맞춰져 있었다 (Subrahmanyam and Castel 2014:6). 
<그림 3> 학교 등록률(2012년) 및 성별 동등지수(2011년)
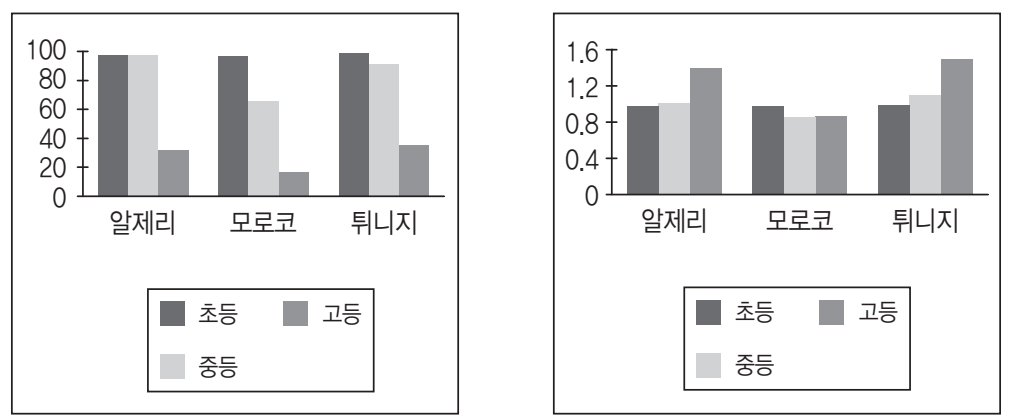

주: 초등교육은 순 등록률(초등학교 연령대에서 초등학교에 등록한 비율) 기준.

증등 및 고등교육은 총 등록률 기준.

출처: 세계은행, World Development Indicators 2013.

그리고 이러한 양적인 인적자원의 투자 증가는 질적인 향상으로 이어지지 못하였다. 학교의 커리큘럼이 문제해결 능력보다는 암기식 교육(on rote learning)에 집중되어 학생들이 치르는 국제 시험기준인 TIMSS ${ }^{7}$ 및 $\mathrm{PISA}^{8}$ 의 성적이 세계 평균치에 훨씬 못 미치고 있다(세계은행 2013b:170).

\section{3) 숙련 불일치(Skill Mismatch)}

2007년 제조업 설문조사에 의하면 제대로 교육받지 못한 노동력(inadequately educated workforce)이 회사 성장의 중요 장애요인이라고 답한 비율이 알제리는 $37 \%$, 모로코는 $31 \%$ 에 이른다. 9)이런 응답률은 세계 평균치인 $28 \%$ 보다 높은 수치이고 개발도상국에서 가장 높은 비율이다(세계은행 2013b:172). 또한 같은 설문조사 가운데 회사에서 훈련(training)을 통해 부족한 역량을 보충해 준다고 답한 경우도 알제리는 $17 \%$, 모로코는 $25 \%$ 에 그쳐 세계 평균치인 $35 \%$ 에 훨씬 미치지 못하는수치이다.

<표 4>에서 볼수 있듯이 실업률은 학력과 비례하여 증가함을 보여준다. 튀니지의 경우 고학력일수록 실업률은 더 높다. 이런 숙련 불일치는 교육과정이 민간부문의 수요에 부합되지 못하기 때문이다. 예를 들어 산업화 과정에서 기업체들은 이공계 졸업생을 선호하는데 이 지역 대학생들의 전공비율은 사회과학이나 인문학 분야가 이공계보다 훨씬 더 높은 수준이다(세계은행 2008:20).

7) TIMSS(Trends in Mathematical and Science Study)는 8학년 대상의 수학 및 과학 시험성적으로 2007년 아주 낮은 성적(<400)층의 비율이 국제평균 $25 \%$ 인데 비해 알제리와 모로코의 경우는 $59 \%$, 튀니지는 $39 \%$ 를 차지한다.

8) PISA(Program for International Student Assessment)는 15세의 학생들 대상의 시험으로 역시 국제평균치에는 미달하는 수준이다.

9) www.enterprisesurveys.org 참조. 
$<$ 표 4> 튀니지 학력별 실업률 비교

(단위: \%)

\begin{tabular}{|c|c|c|c|c|}
\hline & 2005 & 2007 & 2009 & 2011(5월) \\
\hline 無교육 & 6.3 & 4.4 & 6.1 & 8.0 \\
\hline 초등교육 & 14.3 & 11.5 & 10.4 & 12.4 \\
\hline 중등교육 & 13.3 & 13.5 & 14.0 & 20.6 \\
\hline 고등교육 & 14.0 & 18.2 & 21.9 & 29.2 \\
\hline
\end{tabular}

출처: Boughzala(2013).

\section{2. 노동시장의 수요 측면}

\section{1) 공공부문}

앞에서는 청년 실업의 원인을 노동공급 측면에서 살펴보았다면 이번 장에서는 노동시장의 수요 측면에서 알아보기로 한다. 아랍 국가의 경제발전은 전형적인 국가주도형 발전 모델이다. 자원이 풍부한 국가는 정부 산하 공기업이 자원을 발굴하고 채취해서 국가의 부를 축적하는 수단으로 활용했으며, 축적된 부를 가지고 정부기관이나 공기업의 일자리를 늘려 나갔다. 그리고 민간부문보다 높은 임금을 지급하면서 공공부문의 일자리는 국가의 소득 재분배 수단으로 활용되었다(Said 2001:3).

특히 이런 현상은 오일 생산 국가일수록 심하였다. 알제리는 1990년대 초 공공부문에 근무하는 근로자 수가 전체 고용에서 차지하는 비중이 3 개국 중에서 가장 높은 $57 \%$ 를 차지하였으며 모로코와 튀니지도 20\%를 넘었다(Said 2001:5). 특히 고학력자들이 공공부문 일자리를 선호하였는데 민간부문의 일자리 부족, 평생직장 및 관대한 혜택 등이 주요 원인이었다(세계은행 2004:95). 한편 알제리 여성은 전체 근로자의 $85 \%$ 가 공공부문에 종사하였다. 1990년대 들어오면서 여성 경제활동 인구가 증가하였으며 민간부문에 비하여 성차별이 심하지 않고 산후 휴가 등 근무조건이 양호한 수준이었다. 2011년 알제리의 공공부문 고용 비중은 40\%로 줄었고 모로코도 그 비중이 절반 정도로 줄어들었으나 튀니지는 여전히 20\%의 고용 비중을 차지하고 있다(세계은행 2013b:148).

최근 북아프리카, 중동, 코카서스(Caucasus) 및 중앙아시아 지역을 대상으로 공공부문의 고용이 실업률에 미치는 영향을 분석한 논문에 의하면 공공부문의 고용은 구축효과(crowding out effect)를 일으켜 민간부문의 고용을 위축시키고 실업률 감소에 어떤 영향도 주지 않는 것으로 확인되었다. 결국 인위적으로 정부가 공공부문에 일자리를 만드는 것은 정부 재정에 부담만 초래하고 경제의 장기적인 발전을 저해하는 것으로 밝혀졌다(Behar and Mok 2013:24). 
아래 <표 5>는 중앙정부(central government) 임금이 GDP에서 차지하는 비중과 중앙정부의 지출이 GDP에서 차지하는 비중을 보여주고 있다. 3개국은 2000년대에 비하여 임금이 GDP에서 차지하는 비중과 중앙정부의 지출이 GDP에서 차지하는 비중이 큰 폭으로 증가하였다. 특히 알제리는 중앙정부 지출이 전체 $\mathrm{GDP}$ 에서 $45 \%$ 를 차지하고 있다.

$<$ 표 5> 중앙정부 임금이 GDP에서 차지하는 비중

(단위: \%)

\begin{tabular}{c|c|c|c|c}
\hline \multirow{2}{*}{} & \multicolumn{2}{|c|}{ 임금(GDP 비중) } & \multicolumn{2}{c}{ 지출(GDP비중) } \\
\cline { 2 - 5 } & 2000 & 2012 & 2000 & 2012 \\
\hline 알제리 & 7.0 & 12.3 & 28.6 & 45.2 \\
\hline 모로코 & 10.7 & 10.9 & 29.1 & 35.2 \\
\hline 튀니지 & 10.5 & 12.5 & 25.2 & 31.3 \\
\hline
\end{tabular}

출처: AfDB, Socio-Economic Database 2014.

\section{2) 비공식 경제(Informal economy)의 활성화}

위에서 언급한 비대한 공공부문은 민간부문의 발달을 저해하였으며 취직하지 못한 청년들은 비공식 경제(informal economy)에 참여하게 된다. 북 아프리카 및 중동지역의 전형적인 한 국가를 예로 들면 경제활동의 $1 / 3$ 은 공식통계에 잡히지 않으며 전체 노동력의 $67 \%$ 가 의료보험이나 연금혜택이 없는 비공식 경제활동에 참여하고 있다(세계은행 2013a:5).

<그림 4>는 경제활동인구 중에서 사회보장제도(social security)에 가입되어 있지 않은 경제활동 인구의 비중을 보여주고 있다. 선진국의 경우 사회보장제도에 가입되어 있지 않은 경제활동인구 비중이 $9 \%$ 에 불과한 반면 모로코는 전체 경제활동 인구 중 $80 \%$ 가 사회보장제도에 가입되어 있지 않다. 이런 근로자들의 임금은 최저임금제 같은 근로기준의 적용을 받지 못해 근로조건이 열악할 수밖에 없다. 또한 이렇게 큰 비중의 비공식 경제는 공식적으로 경제활동을 영위하는 기업들에게 세금 부담을 전이시키고 이로 인해 경제성장을 주도할 수 있는 새로운 기업들의 출현을 저지하게 된다. 


\section{$<$ 그림 4> 비공식 경제활동비율}

(단위: \%)

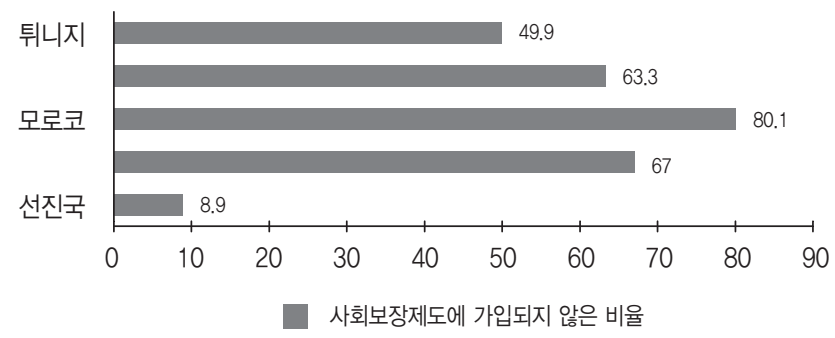

출처: 세계은행(2011).

한편 세계은행이 2014년 발표한 사업 용이성(ease of doing business) 보고서10)에 의하면 세계 189 개 국가 중 알제리는 153 위로 최하위권 그룹에 속한다. 청산 절차 및 투자자 보호 항목을 제외하고 재산권 등록, 세금 납부 및 창업 등의 거의 모든 항목에서 최하위 권에 속하고 있어 이런 비즈니스 환경도 민간부문의 발달을 저해하는 요소로 작용하고 있다. 반면 모로코와 튀니지는 각각 87위, 51 위로 알제리보다는 비즈니스 환경이 용이한 편이다. 같은 보고서의 2012년 자료에 의하면 알제리는 창업환경도 모로코 및 튀니지에 비해서 열악한 실정이다. 근로자 천 명당 신규 사업체 등록 건수도 0.53 을 기록해 모로코와 튀니지의 1.26 및 1.52 에 비해 저조한 것으로 나타났다.

\section{IV. 마그레브 3 개국 노동시장정책 ${ }^{11)}$ 및 사례}

앞 장에서는 1960 1990년까지 인구 증가로 인한 1990년대 경제활동 인구가 증가하면서 압박이 가해지던 노동시장의 현황에 대해서 살펴보았다. 특히 인적자본투자의 증가로 인해 고학력 청년층 증가가 두드러졌었다. 1980년대 중반 이후 오일 붐이 끝나고 국가에서 공공부문의 일자리를 늘려 노동수요를 충족시키는 정책이 마무리되면서 청년 실업 문제가 커지게 되었다.

이 지역은 '아랍의 봄’ 이후 고용문제를 해결하기 위해 다양한 시도를 하고 있다. 공공기관의 임금 상승(알제리 및 모로코), 민간부문 최저임금 향상(알제리, 모로코 및 튀니지), 대학 졸업생을 위한 공공기관의 일자리 창출, 적극적 노동시장정책의 확대 등이 대표적이다(Musette 2013:6). 이번 장에서는 이런 노동시장의 구조적인 문제를 해결하기 위한 노동시장정책에 대해서 살펴보기로 한다. 이 지역 노동시장정책의 특징은 청년층의 '고용능력(employability)' 및 일자리 창출을 목표로 한다.

10) www.doingbusiness.org 참조.

11) 문헌에서는 노동정책(labor policy), 고용정책(employment policy) 및 노동시장정책(labor market policy)이 혼용해서 쓰인다. 본 논문에서는 노동시장정책이라고 한다. 
이는 경기불황 혹은 기업구조조정에 따라 대량 해고된 실업자의 최저생계를 보장해주고 재취업을 지원해 주는 선진국의 노동시장정책과 비교된다.

\section{1. 노동시장정책 개요}

노동시장정책은 수동적 노동시장정책(passive labor market policy)과 적극적 노동시장정책(active labor market policy)으로 나누어진다. 수동적 노동시장정책은 실업상태나 구직상태에서 일시적인 임금의 대체수단(예를 들면 실업보험, 일시적인 실직 수당)으로 혜택을 받는 사람들에게 조건을 부여하지 않는다. 반면 적극적 노동시장정책은 실업자나 구직자가 '적극적'으로 구직을 알아보는 행동을 취해야만 한다. 최근에는 세계적으로 경기불황에 따른 정부의 긴축재정으로 예산을 더 효율적으로 쓰고 적극적 구직활동 참여로 구직기회를 높이기 위해 수동적 노동시장정책에서 적극적 노동시장정책으로 전환되고 있다(Auer 외 2008:69).

본 논문의 연구대상 국가인 알제리, 모로코 튀니지 3개국은 청년층을 대상으로 하는 적극적 노동시장정책을 채택하고 있다. 3 개국이 적극적 노동시장 정책을 쓰는 이유는 개발도상국의 경우 실업보험과 같은 사회적 보호 장치가 미흡하다는 점과 대학교 졸업 후 처음으로 구직활동을 함에 따라 이전 직장 경험이 없는 경우가 대다수이기 때문이다(Fortuny and Husseini 2010:26).

적극적 노동시장정책의 역사는 1930년대의 대공황 시대까지 거슬러 올라갈 수 있지만 제대로 형식을 갖춘 것은 1950 년대 후반이다. 이 정책은 스웨덴을 비롯한 유럽 국가들이 가장 먼저 적용하기 시작했으며 사회적 안전장치가 잘 구비된 유럽지역에서 가장 활발하게 이용되고 있다(Auer 외 2008:31).

\section{1) 적극적 노동시장정책의 목적 및 수단}

적극적 노동시장정책의 목적은 고용능력 향상, 일자리 창출 및 빈곤구제의 세 가지로 구분될 수 있다. 특히 빈곤구제는 개발도상국에서에 유용한 목적이다. '괜찮은 일자리'는 빈곤탈출을 위한 최고의 보험이고 비공식 경제활동의 열악한 환경에서 일을 하는 근로자들에게 더 좋은 조건의 일자리를 마련해 줄 수 있다(Auer 외 2008:21).

이를 달성하기 위한 수단과 수단별 장단점을 정리하면 다음과 같다. 첫째, 고용서비스(employment service)이다. 구직자와 고용주를 중개해주는 서비스로 일자리 알선, 상담 및 정보교환 등을 지원해준다. 과거에는 주로 공공기관에서 제공하는 고용서비스가 주를 이루었지만 최근에는 민간에게 위탁되어 운영되는 추세이다. 공공고용서비스는 소외계층 및 장기구직자를 대상으로 하는 반면 민간고용서비스는 주로 현재 취업 중이거나 숙련 근로자 및 화이트칼라를 대상으로 한다. 다른 수단에 비해 상대적으로 비용이 적게 드는 장점이 있지만 자중손실(自重損失, deadweight loss) ${ }^{12}$ 의 단점이 있다. (Betcherman 2004:4).

12) 다른 사람에 비해 이런 수단의 도움이 없이도 일자리를 구할 수 있는 경우를 말한다. 
둘째, 훈련과 재훈련(training and retraining)이다. 적극적 노동시장정책 수단에서 가장 흔하게 쓰이는 수단으로 고용능력을 높여서 취업 가능성을 높일 수 있는 장점이 있는 반면 비용이 많이 드는 단점이 있다. 다른 국가의 경험에 비추어 보면 훈련의 효과가 극대화되기 위해서는 강의실 및 직장 내 훈련(on-the-job-training), 생활기술, 카운슬링 등이 포함될 경우 효과가 더 높다(세계은행 2013b:5).

셋째, 임금보조(wage subsidy) 수단이다. 근로자의 임금을 직접적으로 보조해주거나 고용주의 사회보험 부담금을 지원해 주는 방식으로 일자리 창출에 기여 할 수 있는 장점이 있지만 자중손실의 단점도 있다.

넷째, 공공 일자리사업(public works)이다. 공공 일자리사업수단은 취로사업을 통한 인프라 구축의 장점이 있지만 일시적인 지원에 불과하고 장기적인 일자리로는 연결되지 않는 단점이 있다.

다섯째, 창업이다. 스타트업에 재정적인 지원, 코칭 서비스 및 보육서비스 등이 포함된다. 창업에 드는 비용을 지원해 줌으로써 자금 확보에 어려움이 있는 창업주를 지원해 줄 수 있는 장점이 있지만 기업가 정신이 있는 특정계층만을 대상으로 한다는 점에서 범위가 좁은 단점이 있다.

다섯 가지 수단 중 고용서비스 및 훈련(재훈련 포함)은 고용능력을 향상시키는데 주목적을 두고 있고 임금보조, 공공 일자리사업 및 창업은 직접적인 일자리 창출과 관련이 있다.

\section{2) 적극적 노동시장정책의 재원}

적극적 노동시장정책은 정부 재원, 기업체 부담금, 공적개발원조(Official Development Assistance 이하 ODA), 및 민관협력(public private partnership 이하 PPP) 등이 주요 재원으로 활용되고 있다 (Caves 외 2009;24). 덴마크, 네덜란드 및 스웨덴같이 사회보장제도가 잘 구축된 국가에서는 연간 $\mathrm{GDP}$ 의 $1.5 \sim 1.8 \%$ 를 적극적 노동시장정책에 쓰고 있지만 개발도상국에서는 이런 예산 지출이 현실적으로 불가능하다. 이 지역 개발도상국의 경우 민간기관에서 운영되는 프로그램은 공적개발원조 재원이 주로 활용되고 있는데 미국 국제개발기구(United States Agency for International Development), 국제연합공업개발기구(United Nations Industrial Development Organization) 및 독일 국제협력기구(GIZ) 등이 대표적이다. 한정된 재원으로 정책의 수행이 어려운 개발도상국은 대외원조 자금으로 구성된 세계 신탁기금(global trust fund)이 제안되기도 하였다(Auer, 2008:73). 아래 <표 6>은 적극적 노동정책의 목적, 수단 및 재원주체를 정리한 것이다. 
<표 6> 적극적 노동시장정책 정리

\begin{tabular}{c|l|l}
\hline \multicolumn{1}{c|}{ 목적 } & \multicolumn{1}{|c|}{ 수단 } & \multicolumn{1}{c}{ 재원주체 } \\
\hline \multirow{2}{*}{ 고용능력 } & 고용서비스 & 정부 \\
\cline { 2 - 3 } & 훈련(재훈련) & 정부, ODA, 기업체, PPP \\
\hline \multirow{3}{*}{ 일자리 창출 } & 임금보조 & 정부 \\
\cline { 2 - 3 } & 공공일자리 & 정부, ODA \\
\cline { 2 - 3 } & 창업 & 정부, ODA, 기업체, PPP \\
\hline
\end{tabular}

주: 저자 재구성.

출처: Cazes 외(2009).

\section{2. 마그레브 3 개국 적극적 노동시장정책 사례}

최근 추세는 앞서 설명된 적극적 노동시장 정책의 각 수단이 별개로 쓰이기보다는 종합적인 패키지 형식으로 바뀌어 가고 있고 제한된 취업 기회 및 공공부문의 일자리 축소로 창업 및 기업가정신 (entrepreneurship) 함양에 대한 지원이 증가하고 있다.

\section{1) 적극적 노동시장정책의 국가별 사례}

이 지역은 청년층의 높은 실업률로 인하여 적극적 노동시장정책이 아프리카 및 중동지역에서 가장 활발하게 전개되고 있다. 모로코와 튀니지는 1980년대 후반부터 1990년대 초반까지 도로, 댐 등의 인프라를 건설하는 공공 일자리사업으로 활용하였다. 모로코는 30년간 국가부흥(Promotion Nationale)으로 인해 전체 경제활동 인구의 $0.6 \%$, 튀니지의 경우 전체 경제활동인구의 $2.7 \%$ 를 흡수하는 정책을 펴왔다(세계은행 2004:155).

3 개국 중에서는 튀니지가 1981년 가장 먼저 적극적 노동시장정책을 도입했으며, 북아프리카 및 중동지역에서 가장 큰 규모의 다양한 프로그램을 실시하고 있다. 2011년 기준 GDP의 $0.8 \%{ }^{13)}$ 를 할애하여 연간 40만 명 이상이 혜택을 받고 있다(세계은행 2013a:130). 가장 일반적인 수단은 임금보조로 단순한 현금지원뿐 아니라 고용서비스, 훈련 및 인턴쉽 등을 포함한 종합 패키지 형식으로 제공되고 있다. 자세한 세부 정책은 <별첨1>에 요약 되어있다.

튀니지에서 가장 오래 시행되고 있는 정책은 1987년에 도입된 임금보조 수단인 SIVP(Stage d’Initiation á la Vie Professionnelle)이다. 대학교(혹은 동등자격)이상 학력소지자가 처음 구직을 하는 청년층을 대상으로 150 디나(약 미화 100 불)의 현금, 사회보험제도 가입 및 직업훈련 비용을 제공하고 있다. 2011년 기준 이 정책으로 혜택을 받고 있는 자는 약 46,000명이다.

13) 2011 년 $\mathrm{OECD}$ 평균 적극적 노동시장정책의 지출은 $\mathrm{GDP}$ 의 $0.6 \%$ 수준이고 우리나라의 지출은 $\mathrm{GDP}$ 대비 $0.3 \%$ 수준이다(stats.OECD.org). 
재스민 혁명 이후 2011년 3월 튀니지 임시정부는 청년 실업층의 불만을 잠재우고자 앞서 언급한 SIVP에 고용서비스를 추가한 종합 패키지 정책(AMAL, 아랍어로 '희망')을 도입했다. 이 프로그램은 한 달에 200 디나(미화 150 불)의 현금제공과 더불어 커리어 카운슬링, 직업훈련, 생활기술훈련 및 적극적인 구직활동을 할 수 있도록 도와주는 정책이다. 프로그램 실시 후 17 만 명이 가입할 정도의 큰 규모의 지원 정책이다.

우리나라의 무상원조사업 기관인 코이카(KOICA)에서는 튀니지의 고용서비스 환경개선을 위해 2010년부터 2012년까지 300만 불의 예산을 들여 직업훈련 및 직업훈련 및 고용부(Ministry of Vocational Training and Employment) 산하 고용처(National Agency for Employment and Independent Work)의 고용서비스 환경개선 사업을 수행하였다. 튀니지 고용처의 열악한 인트라넷 환경, 기자재 및 장비의 노후화, ICT 전문지식과 경험부족을 시스템 개발 및 기술이전, ICT 인프라 개선에 필요한 기자재 및 이동고용센터 버스 지원, 전문가 파견 및 초청 연수 등의 사업 지원을 하였다.

모로코도 튀니지와 유사한 임금보조, 훈련 및 창업지원 등의 프로그램을 운영하고 있다. 국가가 제공하는 프로그램은 $\mathrm{GDP}$ 의 $0.1 \%$ 를 할애하고 있으며 튀니지와 달리 다수의 민간업체에 위탁하여 운영하는 경우가 많다. 모로코의 ALEF(Advanced Learning and Employability for a Better Future) 는 북아프리카 및 중동지역에서 가장 크게 운영되는 민간기관 프로그램이다. 이 정책은 생활기술, 직업교육, 창업 및 고용서비스까지 포함하는 종합적인 프로그램으로 연간 수혜자는 270,000 명이고 연간 운영비용은 27.6백만 불에 달한다(Angel-Urdinola 외 2010).ALEF의 재원은 미국 국제개발기구 (United States Agency for International Development)가 지원해주고 있다.

알제리는 일자리 창출이 정부의 최우선 액션 플랜으로 청년층 일자리 창출을 최우선 과제로 하고 있다. 2010년 2014년까지 5년에 걸쳐 350억 디나(미화 약 47억불)의 예산을 배정하여 3백만 개 이상의 일자리 창출을 목표로 하고 있다(Fortuny and Husseini 2010:25). 알제리는 오일 수출로 축적한 재원을 바탕으로 공공 일자리사업 및 임금보조 정책으로 청년층과 미숙련 구직 대상자를 지원해주고 있다. 튀니지와 모로코와는 다르게 창업을 지원해 주는 정책의 수혜자는 극소수에 불과하며 창업지원 정책도 극히 제한적이다(Achy 2010:23).

\section{2) 창업 관련 적극적 노동시장 정책 사례}

마그레브 3 개국 중 청년층의 창업 부문에 가장 적극적인 정책을 펼치는 국가는 튀니지이다. 정보통신부(Ministry of Communication and Information Technology) 산하 엘가젤라(Elgazala) 테크노파크 ${ }^{14)}$ 는 현재 15 개 지역별 사이버 파크를 운영하면서 ICT 스타트업을 지원하고 있다. 사이버 파크는 사무 공간 제공, ICT 인프라 지원 및 인큐베이션 서비스를 제공하고 있으며 2013년 말 기준 총 136 개의 스타트업이 입주해 있으며 880 명의 고용창출 효과를 나타내고 있다.

14) 튀니지 수도 튀니스에 위치한 엘가젤라 테크노파크는 1999년 북아프리카 지역 최초의 테크노파크로 현재 91개의 다국적기업(Alcatel-Lucent, Microsoft Innovation Center, Ericsson 등)이 입주해 있으며 총 2,172명이 근무하고 있다. 
한편 세계은행은 튀니지 정부와 공동으로 대학졸업생들의 창업을 유도하기 위하여 2009년 새로운 창업지원 정책을 도입했다. 대학교 마지막 학기에 졸업 논문을 쓰는 대신 비즈니스 사업계획서를 제출하는 프로그램(concurs de memoires)이다. 콘테스트를 통해 선발된 학생에게 창업에 필요한 자금을 지원해 주는 프로그램으로 사업계획서를 준비하는 동안 비즈니스 훈련과 개인 맞춤형 코칭도 함께 제공된다. 프로그램 시작 이래 튀니지 국립 12 개 대학의 3 학년생 ${ }^{15)} 1,702$ 명이 참여했으며 이는 전체 대학 3학년생의 약 9\%에 해당하는 수치이다(Premand et.al 2012:9).

선진공여국 사례로는 독일 GIZ를 예로 들 수 있다. 튀니지 제 1 위 이동통신 사업자인 튜니지아나 스타트업 팩토리(Tunisiana Startup Factory)의 대학(원)생 및 청년 기업가들의 ICT분야 ${ }^{16)}$ 창업 및 기업가 정신 함양을 위한 비즈니스 인큐베이터, 창업 경진대회, 멘토링 및 비즈니스 상담 서비스 등을 지원하고 있다. 이 프로젝트는 2012년 1월부터 2015년 11월까지로 총 1,093,020유로를 지원할 계획이다(GIZ 2013:5). 특이 사항으로는 튜니지아나가 1.2백만 유로를 지원하고 스타트업 사업성과에 따라 GIZ가 지원하는 일종의 매칭 펀드 개념을 도입하고 있다(GIZ 2014:5).

국제연합공업개발기구(United Nations Industrial Development Organization)는 2008년부터 Hewlett Packard(HP)사와 민관협력 방식으로 기업가정신 및 IT 훈련 지원을 지원해줌으로 새로운 스타트업 및 일자리 창출에 기여해 오고 있다. UNIDO-HP 협력 파트너쉽 프로그램은 알제리, 모로코, 튀니지를 비롯한 중동지역의 5개국에서 14 개의 LIFE(Learning Initiatives for Entrepreneurs) 훈련센터를 설립, 운영해 오고 있다. 튀니지 LIFE프로그램은 청년 실업률이 높은 엘 께프(el Kef), 까이루안(Kairouan), 캐서린(Kasserine) 및 시디브지드(Sid Bouzid)에서 운영되고 있으며 연간 예산은 3 백만 불로 최소 2,000 개 이상의 일자리 창출을 목표로 하고 있다.

\section{3. 적극적 노동시장정책 평가 및 시사점}

마그레브 3개국은 청년 실업문제를 해결하기 위해 많은 재원을 투입해서 적극적 노동시장정책을 실시하고 있다. 그러나 투자결과는 그리 효과적이지 못하다. 예를 들어, 튀니지의 가장 오래된 프로그램인 SIVP는 2011년 예산이 57백만 디나(미화 38백만 달러)임에도 불구하고 2010년 취업률은 고작 $23 \%$ 에 불과하다(<별첨 1> 참조). 최근 발표된 보고서에 의하면 SIVP가 취업에 긍정적인 작용을 했다는 사실을 배제하기는 어렵지만 고용의 질(고용조건 및 급여)을 향상시키지도 못했다는 평가를 내리면서 프로그램의 전면 수정을 권고했다(Broecke 2012:20). 또한 재스민 혁명 이후 임시정부가 실시한 AMAL 프로그램17)도 막대한 재원이 투입되었음에도 불구하고 청년 실업자를 대상으로 한 현금지원 성격이 강해서 고용효과는 매우 미미한 수준이다. ${ }^{18)}<$ 별첨 $1>$ 에서 볼 수 있듯이 4 개 주요

15) 튀니지의 교육제도는 초등교육(9년), 중등교육(4년) 및 대학교육(3년)로 구성되어 있다.

16) 튀니지 ICT분야는 가장 빠르게 성장하는 산업으로 10차(2002 2006) 경제개발 기간 동안 $20.6 \%$ 성장을 기록했으며 11 차(2007 2011) 경제개발 기간 동안에는 $17.5 \%$ 를 성장했다. 2013년 GDP에서 비중은 $7.2 \%$ 이다(튀니지 정보통신부 2013년 활동보고서 및 2014년 전망).

17) 많은 재원이 수반되는 관계로 2014년 현재 이 프로그램은 중단된 상태이다.

18) 2011년 3월부터 12월 사이 보조금 받은 사람 144,536명에서 6,708명만이 취직했다(세계은행 2013a:148). 
프로그램 취업률은 20\% 수준이고 2013년 튀니지의 최저임금은 월 119불 수준 ${ }^{19)}$ 인데 반해 지급되는 보조금도 지나치게 관대한 면이 있다. 결론적으로 튀니지에서 15세 24세까지의 경제활동 가능인구가 60 만 명이고 전체 수혜자가 40 만 명임을 감안하면 적극적 노동시장정책의 성과는 미약한 형편이다.

최근 세계은행조사연구에 따르면 이 지역 국가가운영하는 노동시장정책은 제도상 장치(institutional arrangement) 및 운영상의 여러 문제점으로 시스템의 단절, 제한적인 행정 역량, 지배구조와 책임의 부족 및 잘못된 프로그램 디자인 등과 같은 문제점이 지적되고 있다. 예를 들어 시스템 단절의 경우 여러 부처가 서로 다른 프로그램을 운영하고 있어 중복과 비효율성의 문제가 제기된다(2013a:13).

또한 튀니지 정부의 적극적 노동시장정책 인지도 조사 결과도 만족할 수준은 아니다. 튀니지 3 개 대학 (원)생을 대상으로 한 설문조사 결과20)에 의하면 전체 응답자 389명 중에 117명(30.1\%)만이 창업과 관련된 적극적 노동시장정책에 대해 인지하고 있다. 대학(원)생들이 인지하고 있는 정책은 가장 오래된 $\operatorname{SIVP}(36 \%)$, 가장 많은 예산을 투입하고 있는 $\operatorname{AMAL}(24 \%)$, 그리고 창업지원을 위한 Programme d'Accompagnement des Promoteurs des Petites Entreprises(PAPPE)의 인지도는 15\%의 순으로 나타났으며 나머지 정책들의 인지도는 $10 \%$ 미만 수준이다.

$<$ 표 7> 튀니지 적극적 노동시장정책 인지도 설문조사 결과

(단위: \%)

\begin{tabular}{c|c|c|c}
\hline 구 분 & 남자 & 여자 & 전체 \\
\hline AMAL & 21.1 & 28.7 & 24.0 \\
\hline SIVP & 37.8 & 31.9 & 35.5 \\
\hline CAIP & 9.0 & 4.8 & 7.4 \\
\hline SCV & 10.4 & 8.0 & 9.4 \\
\hline CRVA & 2.0 & 4.8 & 3.1 \\
\hline PC50 & 6.4 & 5.3 & 6.0 \\
\hline PAPPE & 13.4 & 16.5 & 14.6 \\
\hline
\end{tabular}

주: 적극적 노동시장정책 종류별 소개는 별첨 1 참조

출처: 김창건(2014).

이와 같은 문제점을 해결하기 위해서 세계은행은 다음 네 가지를 제안하고 있다(2013a). 첫째, 성과 중심의 민관협력형 프로그램 개발이다. 훈련 및 고용서비스를 민간기관에 위탁으로 맡기되 취업률을 기초로 한 성과중심의 계약이어야 함을 강조하고 있다. 그리고 고용서비스에 대해서는 공공고용서비스기관이 민간기관과 협력하여 ICT기술을 접목한 고용서비스를 추천하고 있다. 둘째,

19) www.doingbusiness.org 참조.

20) 2014년 4월 29일부터 5월 17일까지 Sup'Com(Ecole Supérieure des communications de Tunis), ESPRIT(Ecole Sup Privée d'Ingénierie et de Technologies) 및 ISET'Com 등 3개 대학(원) 대상으로 'ICT 창업 생태계 조성을 위한 창업의지' 설문조사 36 개 문항 중에서 적극적 노동시장정책 인지도와 관련된 두 개 문항에서 발췌. 
성과 중심의 모니터 및 평가 체계이다. 가장 유효한 정책의 발굴, 모범사례 공유 및 지역 고용기관의 역량 강화 및 전반적인 정책 집행의 효율성 제고를 위하여 독립기관에 의한 엄격한 기준의 평가를 강조하고 있다. 셋째, 기업가 정신의 함양, 직업훈련 및 평생 기술 교육의 강화이다. 기업가 정신 교육 및 일대일 코칭을 통한 창업 활성화는 일자리 창출의 중요한 수단이다. 특히 대학교 졸업생을 대상으로 한 기업가 정신 함양 프로그램은 중요한 정책적인 수단이 될 수 있다. 넷째, 시스템과 프로그램의 연계성 강화이다. 현존하는 적극적 노동시장정책의 점검을 통하여 중복되거나 비효율적인 프로그램은 과감하게 정리하고 종합적이고 체계적인 프로그램의 개발이 시급함을 지적하고 있다.

제I장

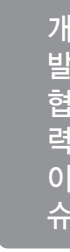

제 II장 제 III장

제 $\mathrm{IV}$ 장

지금까지 북 아프리카 튀니지를 비롯한 알제리 및 모로코의 노동시장 현황과 노동시장의 구조적인 문제를 해결하기 위한 적극적 노동시장정책에 대하여 고찰하였다. 이 지역은 1960년대부터 1990 년대까지 인구학적인 변화로 인해 급속하게 늘어난 경제활동 인구가 노동시장에 참여하였지만 중동지역의 오일 붐 이후 경제상황 변화를 반영하지 못한 채 민간부문 일자리 창출이 부진하면서 청년 실업이라는 문제를 낳게 되었다.

마그레브 3 개국의 심각한 청년실업 문제는 짧은 시간에 정부의 노력만으로 해결하기 어렵다. 노동시장정책에 대한 전문성이 유럽 지역이나 선진국에 비해 떨어지고 재원 면에서 국제사회의 도움이 절실하다. 최근 $\mathrm{UN}$ 및 산하기구, $\mathrm{EU}$, 국제노동기구(ILO), 세계은행 프로젝트 등 국제기구 및 선진공여국의 일자리 창출 사업이 활발해지고 있다. 특히 국제노동기구(ILO)는 2012년 Post 2015 MGD 개발 아젠다에서 '일자리는 곧 개발을 의미(job means development)'라고 강조하였다(ILO 2012).

우리나라 무상원조사업 중점 분야는 교육, 공공행정, 보건, 산업에너지 및 농어촌 개발이다. 교육 분야에서 2015년까지 MDG(Millenium Development Goal) 목표는 절대빈곤 감소를 위한 수단으로 일자리 창출, 보편적 초등교육 및 양성평등을 목표로 하고 있다. 마그레브 3 개국은 앞의 3 장에서 살펴본 것처럼 보편적 초등교육 및 양성평등 목표는 이미 달성하였다. 현재 직업훈련 및 고등교육 분야에서 고용이 다루어지고 있으며 교육 분야 공적개발원조의 1 차 목적은 질 좋은 교육의 제공이기 때문에 지금까지 고용이 직접적으로 다루어지고 있지 않은 상황이다. 하지만 향후에는 개발도상국의 높은 청년 실업률을 감안하여 $\mathrm{MDG}$ 를 대체할 2016년 개발목표에서 고용이슈는 중요하게 다루어질 전망이다.

이에 맞추어 우리나라의 공적개발 원조도 향후 중동지역 및 사하라이남 아프리카 지역 일자리 창출을 위한 지원이 늘어날 전망이다. 현재 마그레브 3 개국은 정부의 재원과 국제사회의 도움으로 많은 재원이 투입되어 다양하고 적극적인 노동시장정책을 실시하고 있으나 제도적 장치와 운영상의 문제점을 가지고 있다. 하지만 위의 사례 분석을 통해 우리에게 시사 하는 점도 많다. 
그 동안 우리나라의 일자리 창출과 관련된 공적개발원조의 지원은 주로 직업훈련센터 설립과 ICT 역량강화를 통한 간접적인 일자리 창출 지원 사업이 주를 이루어 왔다. 그러나 이제는 공적개발 원조의 성공적 성과를 가져오기 위해 ODA의 새로운 성장 동력(engine of growth)을 발굴해야 되는 시점이다.

첫째, 단순한 하드웨어식 지원 대신 프로그램형 지원이 이루어져야 한다. 예를 들어 직업훈련원 건립은 단기적이고 가시적인 성과를 창출하기에는 좋은 사업이다. 하지만 현재는 보다 장기적인 관점에서 노동시장 정책의 국가정책을 입안하거나 개정 할 수 있는 정책 컨설팅형 원조 사업의 발굴이 필요한 시점이다. 이는 적극적 노동시장정책 측면에서 하드웨어형 원조 형식이 향후 프로그램형 원조 형식으로 전환되는 것을 기대할 수 있을 것이다. 특히, 일자리 창출과 관련해서는 대부분의 사업이 국가 정책, 제도 및 법 등과 연계된 활동이 많아 자연스럽게 프로그램형 사업으로 발전될 가능성이 크기 때문이다.

둘째, 우리나라의 ICT 강점을 살려 고용서비스 시스템 및 교육 정보화 시스템 구축에 관심을 가져야 한다. 아프리카 지역은 모바일 브로드밴드가 선진국에 비해 3배 4배 성장하고 있으며 전자정부의 구축도 활발하게 진행되고 있다. 이런 이점을 살려 고용서비스의 ICT화 및 교육 콘텐츠 개발에 더욱 관심을 기울여야 된다. 이에 따라 대외원조라는 명분도 살리고 국내 중소기업의 장비 수출 및 현지 시장 진출의 기반을 준비해 둘 필요가 있다.

셋째, 튀니지와 모로코의 경우처럼 창업 분위기 확산에 더욱 관심을 가지고 집중 할 필요가 있다. 창업은 경제성장과 일자리 창출간의 선순환 구조의 매개체 역할을 수행하고 청년층 실업률을 줄일 수 있는 있는 중요한 수단이다. 특히 ICT분야의 창업생태계 조성은 우리나라의 벤처 경험을 현지에 전파 할 수 있는 유용한 원조방식이다. 또한 최근 우리나라 정부의 창업지원 대책 및 대학에서의 창업 교육 확산과 기업가 정신 함양 교육은 청년 실업 문제의 해결을 위한 대안으로 인식되고 있다. 이런 경험을 바탕으로 개발도상국 대학의 창업교육 프로그램 확산에 관심을 기울일 필요가 있다.

마지막으로 향후 연구 방향은 튀니지 대학(원)생들의 창업의지 설문조사 결과를 바탕으로 대학(원) 생 창업의사 및 창업시기의 결정요인에 대해 분석하고자 한다. 이러한 연구는 창업 의사결정에 미치는 요인을 분석하여 개발도상국 창업 생태계 조성에 기여할 수 있을 것으로 기대된다.

우리나라의 $\mathrm{ODA}$ 사업은 성장 산업이다. 이곳은 지중해라는 지정학적 이점을 살려 앞으로 우리나라 중소기업의 해외진출을 위한 거점이 될 수 있는 지역이다. 향후 우리나라의 공적개발 원조 사업은 단순한 하드웨어형 지원이 아닌 프로그램형 지원으로 전환하고, 고용서비스 시스템 구축 및 ICT 생태계를 활용한 창업 분위기 조성에 힘을 기울여야 된다. ICT분야 및 창업지원 정책은 우리나라가 강점이 있는 분야이다. 이런 장점을 살려 $\mathrm{ODA}$ 의 성장 동력을 발굴한다면 지중해 우리나라 중소기업의 아프리카 및 중동지역의 해외진출의 기반을 마련하고 아울러 청년 실업률을 줄일 수 있는 성공적인 공적개발원조 사업 결과도 가져올 수 있을 것이다. 


\section{<별첨 1> 튀니지 정부의 적극적 노동시장정책}

\begin{tabular}{|c|c|}
\hline 프로그램 & 주요 구성 \\
\hline AMAL & $\begin{array}{l}\text { - 임금보조(일자리 찾기, 코칭, 인턴쉽 포함) } \\
\text { - 자격: 대학(동등자격)이상, 첫 구직자, 최소 } 6 \text { 개월 이상 실업 상태 } \\
\text { - 매월 } 136 \text { 불, 최대 } 12 \text { 개월, 의료보험 제공 } \\
\text { - 고용사무소 매달 갱신 } \\
\text { - } 2011 \text { 년 예산: } 172 \text { 백만불/가입자 수: } 155,000 \text { 명 }\end{array}$ \\
\hline SIVP & $\begin{array}{l}\text { - 임금보조(인턴쉽, 직업 기술 훈련 포함) } \\
\text { - 자격: 대학(동등자격)이상, 첫 구직자 } \\
\text { - 매월 102불, 최대 24개월, 사회보험, 훈련비용 } \\
\text { - 고용주 추가로 최소 매월 102불 지급 } \\
\text { - 2011년 예산: } 39 \text { 백만불/가입자 수: 46,000명 } \\
\text { - 2010년 취업률: } 23.7 \%\end{array}$ \\
\hline CIDES & $\begin{array}{l}\text { - 임금보조(훈련 포함) } \\
\text { - 대학(동등자격)이상, 최소 24개월 실업 } \\
\text { - 매월 102불, 최대 12개월, 훈련비용, 고용주 사회보험 부담 경감 } \\
\text { - 채용시 고용주가 추가 102불 지급, 고용주는 680불 지원 받음 } \\
\text { - 2011년 예산: } 3.4 \text { 백만불/가입자 수: } 3,000 \text { 명 } \\
\text { - 2010년 취업률: } 20.7 \%\end{array}$ \\
\hline CAIP & $\begin{array}{l}\text { - 임금보조(훈련 포함) } \\
\text { - 대학교 이하 학력만 해당 } \\
\text { - 매월 } 102 \text { 불, 최대 } 12 \text { 개월 인턴쉽, 사회보험 포함 } \\
\text { - 2011년 예산: } 19.1 \text { 백만불)가입자 수: 40,000명 } \\
\text { - 2010년 취업률: } 18 \%\end{array}$ \\
\hline SCV & $\begin{array}{l}\text { - 임금보조(자발적 인턴쉽 및 파트타임 공공일자리) } \\
\text { - 대학(동등자격)이상, 첫 구직자 } \\
\text { - 매월 136불, 최대 12개월, 사회보험 } \\
\text { - 2011년 예산: } 7.5 \text { 백만불/가입자 수: } 8,000 \text { 명 }\end{array}$ \\
\hline CRVA & $\begin{array}{l}\text { - 임금보조 } \\
\text { - 3년 이상 경력 실업자, 폐업이나 구조조정 대상 } \\
\text { - 매월 136불, 사회보험, 훈련비용 } \\
\text { - 2011년 예산: } 700,000 \text { 불/가입자 수: } 1,000 \text { 명 }\end{array}$ \\
\hline PC50 & $\begin{array}{l}\text { - 임금보조 } \\
\text { - 대학이상, 첫 구직자, 개발지역내 거주 } \\
\text { - } 50 \% \text { 의 임금(최대 1년). 한도액 매월 } 170 \text { 불 } \\
\text { - } 2011 \text { 년 예산: } 300,000 \text { 불/가입자 수: } 500 \text { 명 }\end{array}$ \\
\hline PAPPE & $\begin{array}{l}\text { - 창업(코칭, 사업계획서, 인턴쉽 포함) } \\
\text { - 잠재적 창업가 } \\
\text { - 매월 } 136 \text { 불(대학 이상), 매월 68불(대학이하) } \\
\text {-최대 } 12 \text { 개월 인턴쉽 } \\
\text { - 2011년 예산: } 2.9 \text { 백만불/가입자 수: } 17,000 \text { 명 }\end{array}$ \\
\hline
\end{tabular}

주: AMAL: Programme de Recherche Active d'Emploi au Profit des Diplomes de I'Enseignement Superieur

SIVP: Stage d'Initiation á la Vie Professionnelle

CIDES: Contrat d'Insertion des Diplomes de l'Enseignement Superieur

CAIP: Contrat d'Adaptation et d'Insertion Professionnelle

SCV: Service Civil Volontaire

CRVA: Contrat de Reinsertion dans la Vie Active

PC50: Prise en Charge par l'Etat d'une Part des Salaires Verses

PAPPE: Programme d'Accompagnement des Promoteurs des Petites Entreprises

출처: 세계은행(2013a) 


\section{<참고문헌>}

김시경. 2003. "북아프리카 국가들의 무역 및 투자환경에 관한 연구: 모로코, 튀니지, 알제리를 중심으로." 『한국중동학회 논총』. 제 24-1호. 한국중동학회. pp. 115-143

김성규. 2013. 『개도국 일자리 창출 사업 지원방안 연구』. 연구보고서. ODA연구. 한국국제협력단.

김중관. 2007. "튀니지의 경제정책의 평가와 예측에 관한 연구: 통상환경과 투자유인을 중심으로."지중해지역연구』. 제 9권. 제 2호. pp. 1-24.

김창건.2014.『튀니지 ICT 창업 생태계 조성을 위한 대학(원)생 창업의지 설문』. Unpublished 내부 보고서. 튀니지: 엘가젤라 테크노파크.

한바란·윤서영·박광순. 2011. 『중동 노동시장 현황 및 우리의 대응: 사우디아라비아와 UAE를 중심으로』. 연구보고서. 서울: KIEP 대외경제정책연구원.

Achy, Lahcen. 2010. "Trading High Unemployment for Bad Jobs: Employment

Challenges in the Maghreb." Carnegie Papers. No. 3. Washington, DC: Carnegie Endowment for International Peace.

AfDB. 2012. Jobs, Justice and the Arab Spring. Tunisia: African Development Bank Group.

Angel-Urdinola, Diego F, A. Semlali, and S. Brodmann. 2010. "Non-Public Provision of Active Labor Market Programs in Arab-Mediterranean Countries: An Inventory of Youth Programs.” Social Protection Discussion Paper 55673. Washington, DC: World Bank.

Auer, Peter, Umit Efendioglu and Janine Leschke. 2008. Active Labor Market Policies Around the World: Coping with the Consequences of Globalization. 2nd Edition. Geneva: ILO.

Behar Alberto and Junghwan Mok. 2013. "Does Public-Sector Employment Fully Crowd Out Private-Sector Employment?” IMF Working Paper. Washington, DC: International Monetary Fund.

Betcherman, Gordon, Karina Olivas, and Amit Dar. 2004. "Impact of Active Labor Market Programs: New Evidence from Evaluations with Particular Attention to Developing and Transition Countries." Social Protection Unit Working Paper. Washington, DC: World Bank. 
Bloom, David and David Canning. 2004. "Global Demographic Change: Dimensions and Economic Significance.” NBER Working Paper Series. No. 10817. Cambridge MA: National Bureau of Economic Research.

Boughzala, Mongi. 2013. "Youth Employment and Economic Transition in Tunisia." Global Economy and Development at Brookings. Working Paper 57. Washington D.C.: Brooking Institution.

Broecke Stijn. 2012. "Tracking Graduate Unemployment through Employment Subsidies: An Assessment of the SIVP Programme in Tunisia." Working Paper Series. No. 158. Tunisia: African Development Bank Group.

Campante, Filipe R. and Davin Chor. 2012. "Why was the Arab World Posed for Revolution? Schooling, Economic Opportunities, and Arab Spring.” Journal of Economic Perspectives. Vol. 26. No. 2. pp. 167-188.

Cazes, Sandrine, Sher Verick and Caroline Heuer. 2009. "Labor Market Policies in Time of Crisis.” Employment Working Paper No. 35. Geneva: ILO.

Deutsche Gesellschaft fur Internationalez Zusammenarbeit(GIZ). 2014. "Cooperation with the Private Sector in Tunisia." Country Reort 2013. Bonn and Eschborn:GIZ. Fortuny, Mariangels and Jalal Al Husseni. 2012. "Labor Market Policies and Institutions: A Synthesis Report. The Case of Algeria, Jordan, Morocco, Syria and Turkey.” Employment Sector Working Paper. No. 64. Geneva: ILO.

Gatti, Roberta, Diego F Angel-Urdinola, Joana Silva and Andras Bodor. 2011. "The Challenges of Informality in the Middle East and North Africa Region.” Overview. Middle East and North Africa Region. Washington. DC: World Bank.

ILO. 2012. "Jobs and Livelihood at the Heart of the Post-2015 Development Agenda." ILO Concept Note. Geneva: ILO.

Keller, Jennifer and Mustapha K. Nabli. 2002. “The Macroeconomics of Labor Market Outcomes in MENA Over the 1990s: How Growth Has Failed To Keep Pace With A Burgeoning Labor Market.” Middle East and North Africa Region. Washington. DC: World Bank.

Malik, Adeel and Bassem Awadallah. 2013. "The Economics of the Arab Spring." World Development. Vol. 45. pp. 296-313. 
Musette, Mohamed Saib. 2013. "Employment Policies and Active Labour Market Programs in Algeria." Algeria Background Paper. Italy: European Training Foundation.

Pissarides, Christopher A. 1993. "Labor Markets in the Middle East and North Africa”. Discussion Paper. London School of Economics. UK: London School of Economics.

Premand, Patrick, Stefanie Brodmann, Rita Almeida, Rebekka Grun and Mahdi Barounni. 2012. "Entrepreneurship Trining and Delf-Employment among University Graduates: Evidence from a Randomized Trial in Tunisia.” Middle East and North Africa Region, Human Development Department, Policy Research Working Paper No. 6285. Washington, DC: World Bank.

Said, Mona. 2001. "Public Sector Employment \& Labor Merkets in Arab Countries: Recent Developments \& Policy Issues”. D. Salehi-Isfahani, ed. 2001. Labor and Human Capital in the Middle East: Studies of Labor Markets and Household Behavior. Reading, UK: Ithaca Press.

Subrahmanyam, Gita. 2011. "Tackling Youth Unemployment in the Maghreb.” North Africa Policy Series. Tunisia: African Development Bank Group.

Subrahmanyam, Gita and Vincent Castel. 2014. "Labor Market Reforms in PostTransition North Africa.” Economic Brief. Tunisia: African Development Bank Group.

Yousef, Tarik M. 2004. "Development, Growth and Policy Reform in the Middle East and North Africa since 1950.” Journal of Economic Perspectives. Vol. 18. No. 3. pp. 91-116.

World Bank. 2008. The Road Not Traveled: Education Reform in the Middle East and North Africa. Washington, DC: World Bank.

World Bank. 2013a. Building Effective Employment Programs for Unemployed Youth in the Middle East and North Africa. Washington, DC: World Bank.

World Bank, 2013b. Jobs for Shared Prosperity: Time for Action in the Middle East and North Africa. Washington, DC: World Bank.

AfDB. Socio-Economic Database 2014. http://www.afdb.org. 
ILO. Key Indicators of Labor Market. 8th Edition. http://www.ilo.org.

Ministry of Communication and Information Technology. Activity Report of 2013 and Prospects for 2014 in Tunisia(아랍어). http://www.mincom.tn.

National Institute of Statistics. Tunisia Foreign Trade. 2012. http://www.ins.nat.tn.

OECD. http://stats.OECD.org.

World Bank. http://www.doingbusiness.org.

World Bank. www.enterprisesurveys.org

World Bank. World Development Indicators 2013. http://www.worldbank.org. 